Research in Social Sciences

ISSN: 2641-5305

Vol. 1, No. 2, pp. 53-59

2018

DOI: $10.53935 / 2641-5305 . v 1 i 2.8$

(C) 2018 by the authors; licensee Academic Publishing Group

\section{The Rise of China: Dream of Xi Jinping}

"Md Ziaur Rahman: Assistant Secretary (Junior Diplomat), Ministry of Foreign Affairs, Government of the People's Republic of Bangladesh.

Nitin Kumar: Business School, Sichuan University, Chengdu 610065, People’s Republic of China.

Jhensanam Anusara: Business School, Sichuan University, Chengdu 610065, People's Republic of China.

Bouasone Chanthamith: School of Public Administration, Sichuan University, Chengdu 610065, People's Republic of China.

Humaira Khatoon: Department of Urdu, University of Dhaka, Bangladesh.

ABSTRACT: The main purpose of this article is to explore the mystery of china being a leader in business, and economic aspects and the dream of Xi Jinping. A historical, analytical, case study method has been used to conduct this research. The study reveals that China has been successful in attaining a stable domestic and international status and achieving a top position in the world. It is proclaimed that "The Dream of Xi Jinping" is for making the nation an ideal one based on the characteristics and ideologies of China. This paper focuses on all the aspects of China as a global leader; it discusses China's economical-political history, struggles for success and policies for becoming a superpower. In addition, Chinese foreign policies and its relationship with the other countries, especially with Bangladesh have been enlightened here. The findings of the study will be helpful for trader, policy makers and enthusiastic to understand, policy making and future trade with China.

Key words: China, Trade relationship, Economic reform, Business agreement, Diplomacy.

\section{Introduction}

China's economic rise has become a major factor of concern for the most powerful countries of the world who are currently dominating global politics under economical hegemony. Currently, China has the second massive economy of the world. China is one of the largest trading States and the second source of outward foreign direct investment (Aoyama, 2016). The gradual transition of China has contributed to increase the country's political power and economic advantages (Sarker et al., 2018; Sarker et al., 2018). China is now increasing the number of State-owned Enterprises while the private sector is also expanding. This magnitude of economic enhancement has been also stimulating countries internal economic evolution. After decades of instabilities in China's National life, the country is now diverting its attention to the global economic governance (Sarker et al., 2019). China has not stated any intentions to manipulate the current international order or to change the rules of global economic governance (Sarker et al., 2018). However, it is imminent that China's growing power, both political and economic may contribute changes in the international system. "The One Belt One Road" initiative is also assumed to stimulate an increase in China's economic and political

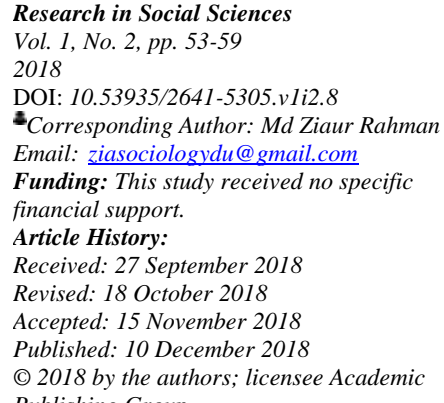


power (Sum, 2018). The one belt one-road initiative is a manifestation by China to unite the neighboring countries to increase trade in the region. It is evident that such manifestations by China will make it a business leader in the regional economic hub. The headquarters of Asian Infrastructure and Investment Bank (AIIB) and the New Development Bank (NDB) are situated respectively in Beijing and Shanghai (Yu, 2017). The establishment of these headquarters in China can challenge financial Institutions like International Monetary Fund (IMF) and the World Bank (Ba, 2014). Economically China has shown a fast growth, at present the country wants to focus on "smart economic growth" instead of a "fast economic growth" with a substitution to intensive and high polluting industries (Cui \& Song, 2018). The Chinese civilization grew in the basin of the Yellow River, East Asia. Since its development of political system, China always had a political system of hereditary dynasties. Among all of the dynasties, Chinese have evolved mostly during the rule of Xia dynasty. China has been through quite vicissitudes; China grew, broke and restructured during this regime. In 2100, the Xia dynasty raised as the first dynasty of China (Ploberger, 2017). The Shang ruled between $17^{\text {th }}$ to $11^{\text {th }}$ centuries, Zhou conquered them and ruled between $11^{\text {th }}$ to $7^{\text {th }}$ centuries. By the end of their ruling seven sovereign states emerged in China. In $221 \mathrm{BCE}$, Qin conquered China and the first emperor of China ruled for only a period of fifteen years. Then Han ruled from 206 BCE to 220 CE ("Han Dynasty - Ancient History Encyclopedia," 2013). During this regime, China expanded considerably. Han China was the largest economy of ancient world. In $220 \mathrm{CE}$ started a period of strife called "three kingdoms"-Wei, Shu, Wu CE. In 265, Jin dynasty overthrew Wei. Later dynasties were the Northern and Southern dynasties, Sui, Tang, Song, Yuan, Ming, and Qing. In the $13^{\text {th }}$ century Kublai khan, establish Yuan dynasty. A peasant "Zhu" overthrew the Yuan dynasty in 1368 and founded the Ming dynasty; this was the golden age of China. Qing was the last dynasty; it lasted from 1644 to 1912. At the beginning, China had a drastic economic situation. Western imperialism, the Opium Wars, internal unrest, deaths, and Chinese Diaspora tapped revolt and revolutions in China, which led to the end of Qin dynasty ("China Northern and Southern Dynasties: Song, Qi, Liang, Chen," 2017). However, this article attempts to explore the mystery of china being a leader in business, and economic aspects and the dream of Xi Jinping. A historical, analytical, case study method has been used to conduct this research. Many journals, newspapers, books, periodicals, social science papers, economic reports, websites are analyzed as well as reviewed with a view to formulating this article.

\section{Modern China}

The modern day China has a population of about 1.42 billion. It is a country in East Asia and shares border with a number of countries which are- North Korea, Russia, Mongolia, Kazakhstan, Kyrgyzstan, Tajikistan, Afghanistan, Pakistan, India, Nepal, Bhutan, Myanmar, Laos, and Vietnam. In 1949, Mao Zedong declared the creation of People's Republic of China. Mao Zedong was the Chinese communist leader. The communist party of China was established in 1921. The communists joined the nationalists in 1926 against the warlords; this alliance prevented the formation of a centralized strong government. The "White Terror" of 1927 turned the both parties against each other. In 1931, the nationalists faced threats from three sidesJapanese invasion in Manchuria, communist upheaval and warlord insurrection. The communists were growing famous on the rural China. The dictatorial policies and wartime policies made the government vulnerable. After the Japanese surrender, a civil war broke out in China. The US still supported the nationalist to prevent the communist control over China. From 1945 to 1949 in the civil war a confrontation between the nationalists and communities lasted. The government had already lost its popularity among the masses because of the corruption and mismanagement. Even though it was nominally democratic, the US continued to provide military support to the nationalists only to suppress communism. The establishment of communist China resulted in the withdrawal of support and diplomatic ties with the US for more than 20 years. America continued to support the Nationalist Chinese government by Chiang Kai-shek on Taiwan. The US and PRC clashed twice from 1950s to 1960s during the Korean War and Vietnam War. However, in January 1, 1979, the United States recognize the communist People's Republic of China (PRC) to benefit from the huge Chinese market, even China saw the necessity to build better relation with the US for the sake of its own benefits. After the Chinese revolution of 1949, the US did not recognize the Mao China for almost 20 years. The US had already imposed containment policies on China, which was initially limited to Europe only. After the establishment of PRC, US continued to recognize the nationalist Chiang Kai-shek who settled his party on Formosa (Taiwan). The trade relation between PRC and US was close to zero percent. This situation worked as an opportunity for China to raise her economy breaking the shackles of Imperialism and eventually it did.

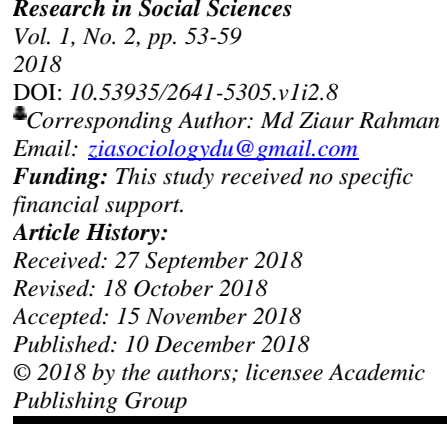


For the national salvation, the communist party of China initiated economic reformation. After the Korean War, the new government adopted the Soviet style five-year plan model (Lee, 2017). When Mao came to power, the Chinese market was lagging behind in the global market. China was left out of the western market. The soviet formed a relationship of friendship and cooperation with China giving her aid and technical assistance. In December 1949, they signed the Treaty of Friendship, Alliance and Mutual Assistance (Benny et al., 2018). The 1953 FYP was influenced by Stalin's five-year plan. It focused to boost industrialization of China; it had both good and bad results. Soon China moved toward a new policy, named "walking on two legs" policy; it refers to the balance between pure science and applied technology (Yu, 2017) which was taken to modernize industry and agriculture. But Mao's 'Great Leap Forward Movement' caused mass starvation and to handle the situation a new program was set by limiting free enterprise, allowing public sector and government enterprises with a new leadership of Liu Shaoqi, Zhou Enlai, and Deng Xiaoping. It created a capitalist stream in China. Mao wanted to preserve communist ideology by the Cultural Revolution from 1966 to 1976. The revolution almost caused another civil war and pushed China into the brink of irreparable damages (Lee, 2017).

The Korean War also had an effect on the Chinese economy as it delayed the economic reform. China's entanglements in the Korean War deterred the growth but not entirely. China managed to grow at an annual rate of 16 percent from 1950 to 1954 (Boon \& Ardy, 2017). Industrial production increased 2.5 times and steel output rose from 0.15 million tons to 2.2 million tons. China continued to invest in heavy industry, weapons production and research facilities, and infrastructure construction. Weapon production and development facilities were provided to different provinces keeping in mind the country's threatening position in global politics (Ba, 2014). Such strategies helped improve Chinese factories as they were producing weapons and employing thousands of workers in the factories. China's development projects an idea that for indigenous development under capitalism a country has to come out of imperialist domination before entering world capitalist system. Otherwise, the domestic market may face a negative impact and aggression of the imperialist multinational companies. US blockade of 1948 helped China to settle a program to sustain the market and economy without any investment from the imperialist countries. With little cooperation from Russian financial assistance and Russian engineers, China started to build its own tools and machineries. The abrupt termination of Russian financial support in 1959 had impacts in Chinese economy. Instead of decreasing the acceleration of growth, China became even more independent in economic sector. From 1950 to 1970 , China saw a tremendous change in the economy; in a period of 20 years, China became a country with zero industry to a country whose economy is entirely supported by indigenous industry.

China saw a period of agricultural collectivization. Under Mao's supervise this era brought mass starvation eventually "The Great Chinese Famine". After Mao's death, Deng Xiaoping reformed collectivization system; the reform resulted in the blossoming of agriculture and helped China recover from the effects of The Great Leap Forward. Chinese industry was built on the agricultural product. Better utilization of means of production-land, labor, and other resources helped the industrialization largely. China had reached in a position by 1970 s in the global market. It chooses to form joint ventures with multinational companies instead of letting the capitalist to dominate the economy of China.

\section{The Economic Rise of China}

The economic history of China is tale of true success. China saw economic reform in 1979, which proved to be very beneficial to the country. The GDP of China has grown $10 \%$ at an average annual rate since then. China has grown out of famine, extreme poverty, war and revolutions. Currently it is the second largest economy of the world with USA on the second position. It is possible China will be at the first position in the upcoming years. The growth of Chinese economy can be observed at six fronts- a) the continual GDP growth rates, b) high quality of the growth, c) comparatively fast credit growth, d) global digital leader, e) economic reform. According to The International Monetary Fund, China accounts for one-third of global growth; 800 million people now are out of poverty and China managed to obtain a upper middle income status. Chinese per capita GDP is closer to that of the United States. China has been displaying growth acceleration for decades, the IMF states that the country should be more focused on the quality of growth for now. Key elements are continuing to rein in credit growth, accelerating rebalancing efforts, increasing the role of market forces, fostering openness, and modernizing policy frameworks (IMF, 2018). Chinese debt in non-financial sector is still on the rise, which is faster than the GDP growth rate in 2017. The country has around 700

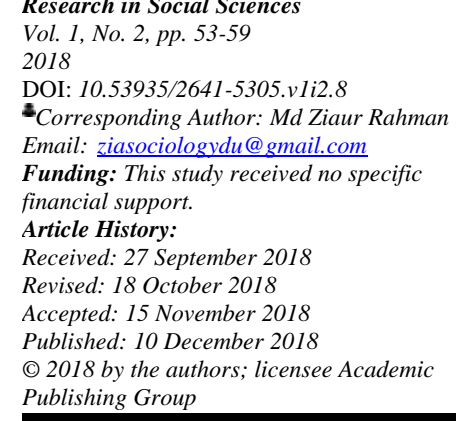


million internet users and 282 million internet users eager to adopt new technology. China has been playing the role of global digital leader as it is on the frontline in the field of e-commerce and fintech (Hossin et al., 2018). China's growing success has inspired other low and middle-income countries; they are eager to follow her footsteps, including countries of Latin America such as Brazil, Argentina, Columbia and India, which also has a large population like China. It is obvious that with the annually at $8 \%-10 \%$ rising GDP of China it will sustain in the economic ranking in the near future. Although China's GDP has converged and surpassed United States GDP, its per capita GDP is still below the U.S. and first world. There is a fair possibility that the difference in GDP between China and other countries will extend more in the future. The United States has a heavy military burden, which does not take in point while reviewing economic growth whereas China has avoided heavy military burden. The silk route traversing China, India, Persia, Arabia, Greece and Italy has been a major international economic development program by China. China inaugurated the enormous project by financing infrastructure projects in the historical silk route countries (Ploberger, 2017). Some major factor worked as a stimulator in shaping China's economic, political and social framework. They are briefly noted below;

\section{Leadership}

The leadership and smooth, peaceful transition of political power has played an important role in flourishing Chinese economy. The Economic reform of 1978 was carried into two stages- first stage in the late 1970s and the second in the early 1980s. The reform introduced market principles, which involved a) the decollectivization of agriculture, b) the opening up of the country to foreign investment, and c) permission for entrepreneurs to start businesses (Sarker \& Jie, 2017; Sarker et al., 2017). Most of the industries were still state-owned (Sarker et al., 2018). Therefore, the second stage of reform involved the privatization and contracting out of much state-owned industry and the lifting of price controls, protectionist policies, and regulations. Deng Xiaoping (1978-1987) did these reforms. He was the man responsible for the initial reforms that brought good fortune for China. After Deng Xiaoping's death in 1997, reforms continued by his successors, Jiang Zemin and Zhu Rongji. The first step of reform was large-scale privatization, which took place in 1997 and 1998; all-state enterprises, leaving a few large monopolies, were liquidated and their assets sold to private investors. Between 2001 and 2004, the number of state-owned enterprises decreased by 48 percent (Hsiao, 2018). Jiang Zemin and Zhu's second reform included- a) the reduction of tariffs, trade barriers, and regulations; b) the reformation of the banking system; c) dismantling of a greater portion of the Mao-era social welfare system; d) forcing the PLA to divest itself of military-run businesses; e) reduction of inflation; and f) joining the World Trade Organization. In 2005, for the first time the domestic private sector first exceeded 50\% of Gross Domestic Product (GDP) and China became the largest economy in Asia exceeding Japan. The domestic private sector first exceeded 50\% of GDP in 2005 and has further expanded since. In 2005, China was able to surpass Japan as the largest economy in Asia. The current President of People's Republic of China Xi Jing ping came into power in March 2013. He launched a series of tasks for the economic development, like- One Belt One Road Initiative for the growth of economic betterment of the silk route countries; he took prevention measures for corruption by rooting out high party members and military brass, he also has launched a rural development program to close distributional and development gaps, and promote social equity (Sarker et al., 2018).

\section{International Trade Orientation}

From 1979 to 1984, Chinese economic policies were readjusted for the better growth of the economy. The economic strategy shifted from self-sufficiency to export orientation. China is emphasizing on building a strong domestic consumer sector to develop an improved domestic market that can play a pivotal role in the economy in future (M. N. I. Sarker, Hossin, Hua, Anusara, et al., 2018). May' 2014 China signed the multibillion dollar natural gas contract with Russia which is a 30 -year, \$400bn ( $£ 237 \mathrm{bn}$ ) deal for Gazprom to deliver Russian gas to China. The deal emphasizes Russia's disputed relations in the west and the countries interest of an economical diversion towards Asia (World Bank, 2018).

\subsection{Growth Rate Performance}

There is a remarkable difference between the annual growth rate of the First World and China. The First World's average annual growth rate is $2 \%$ China has growth rate ranging from $7 \%$ to $10 \%$. From 1891 to 
2007, the United States achieved the annual growth rate $2 \%$ of real par capital GDP. For the next few years, the GDP was almost lower than $2 \%$. On the other hand, China is rising at an annual growth rate of $4 \%$ to $6 \%$ (Barrass \& Inkster, 2018).

\subsection{Macroeconomic Management}

During the Great recession the export of China, dropped from 15 to 18 percent. It had cost 23 million people to become unemployed. Nevertheless, China's sound macroeconomic management helped the economy to bounce back readily. Ninety eight percent of the unemployed people found jobs and the unemployment rate reduced to $4 \%$. On the other hand, many countries of the world were still lingering recession even in 2014. The Great Recession had a contagious, turbulent and transmittable effect worldwide (M. N. I. Sarker, Hossin, Hua, Sarkar, \& Kumar, 2018). However, China escaped this global meltdown effectively because of the successful macroeconomic management.

\subsection{Renewable Energy}

China has a development plan to satisfy $15 \%$ of China's energy needs by the year 2025 . The 12 th Five Year Plan of China emphasized on the development of renewable energy. Fossil fuel will be used as a substitute for energy production on this program. Thus, the development of renewable energy policy is hoped to contribute in reducing pollution and preventing environmental degradation (Sarker et al., 2018).

\subsection{Marine Ships}

According to the United Nations data, China is the world's biggest merchant Marine operator. In the first half of 2014, almost 40000 ships entered and left Chinese ports.

\subsection{Population Policy}

China has a possible population trap. The recent modification of the Government of China, especially the One Child Policy is the most favorable one to control the population. If the fertility rate can be controlled successfully by China, it can assure a long-term growth. China's population is expected to rise at 1.45 billion by 2050; the increased number of populations will reduce the growth rate of China to $0 \%$. The history shows that the population policy of $14^{\text {th }}$ century in Europe helped the Industrial Revolution of $18^{\text {th }}$ century (Sarker et al., 2018). Since then First World has high level of per capita income. It is hoped that the demographic policy in China will result in more economic development (Rahman et al., 2018).

\subsection{Poverty Reduction}

China is the most successful country in the world to successfully reduce poverty in great numbers. Investments in human capital and education are the major growth policies of China (Khan et al., 2018). China has developed growth zones like Shanghai, which attracts foreign direct investment. Hong Kong invests threefifths of China's FDI. Since 1980, China has shown high growth rate by uplifting millions of peasants out of poverty. China has an annual growth rate of $7 \%$ to $10 \%$. This example is remarkable in the world economy (Worldometers, 2018; Sarker, 2016; Sarker et al., 2015).

\subsection{Anti-Corruption Campaign}

Corruption is a worldwide problem which weakens a country from the within. China is also a victim of corruption. Corruption has institutionalized in China and penetrating its culture. The former President of China initiated efforts to reduce corruption. The current president of China Xi Jing ping has followed up his efforts. From 2012 to 2014, 182000-government official were punished and high level party members were removed for engaging in corruption activities (Lam, 2016). The policy of transparency in China is hopeful to clean up corruption. The efforts are instructive for the other countries an admirable at the same time.

\subsection{Unique Features of China's Policy and Polity}

Some of the Hallmark of China's leadership pronouncements are altruism, social cognition, equity, equality, egalitarian motives, public Service and economic growth. China has a unique socio-economic political system it consists of one political party and free competitive market economy (Sarker et al., 2018). The political system is active under a seven-member politburo Standing Committee of party congress. A

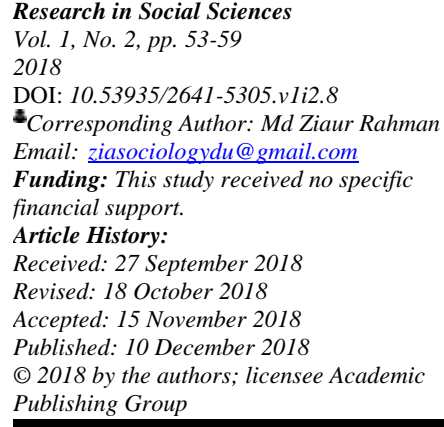


political leader is elected in every five year. Private Enterprises produce almost half of China's gross Domestic Product. China has uplifted most 700 million people from poverty (Sarker et al., 2018). In 2014, the UNESCO awarded the Grand Canal of China, a 2400-year-old historical canal, UNESCO World Heritage status. The Grand Canal is linked up with Silk route. China has linked up Chongqing and Xinjiang with Europe through an $11179 \mathrm{~km}$ Yunxianou International Railway. The railway tracks runs along this ancient Caravan, it is referred as the new Silk road ( Sarker et al., 2018).

\section{Conclusion}

The rising power of China has been very influential in the global politics. China has been dominating the countries around the world, especially in the Asia and the pacific region either as an elite partner or as a diplomatic superpower. China's ambition to rise in the top position in the global arena may pioneer a new World order. In spite of distinct aspects and ideologies with countries like the United States and India, China has managed to exercise diplomatic influence on both the countries. China's current position and the longstanding strategies have given the country advantage to influence according to its own National Interest. China has maintained collaborative relationship in the South Asia, it has strong trading base in the region; it has been supporting Africa financially, which makes it evident that China has been embellished with qualities that is required to turn itself into a global guardian. It is no doubt that the moral authority of the world is now shifting towards China since the election of Donald Junior Trump. China has contributed to science and technology that is admired as "the fourth revolution"; such advancement of China has made it a business leader in technology. Moreover, "The One Belt, One Road" initiative including 'Silk Road' and 'Maritime Road' is the major tools that may lead China to the most prominent status as a trading country. The apparent rise of China will cause the major swap of the balance of power; raise conflict and instability while the global hegemony is going to shift in the East Asia. China's growing success magnitude is going to meet with more growth in the future but it comes along with a few challenges. Like widespread pollution, growing income inequality, incomplete transition to a free market economy and imbalances from economic growth.

\section{References}

Aoyama, R. (2016). One Belt, One Road: China's New Global Strategy. Journal of Contemporary East Asia Studies, 5(2): 3-22. Available at: https://doi.org/10.1080/24761028.2016.11869094.

Ba, A. D. (2014). Is China leading? China, Southeast Asia and East Asian integration. Political Science, 66(2): 143-165. Available at: https://doi.org/10.1177/0032318714557142.

Barrass, G., \& Inkster, N. (2018). Xi Jinping: The Strategist behind the Dream. Survival, 60(1): 41-68. Available at: https://doi.org/10.1080/00396338.2018.1427363.

Benny, G., Daud, S., \& Moorthy, R. (2018). Economic versus Political Liberalisation in ASEAN: Public Opinion among University Students in Four Member Countries. International Journal of Asia Pacific Studies, 14(1): 228-249. Available at: https://doi.org/10.21315/ijaps2018.14.1.9.

Boon, H. T., \& Ardy, C. (2017). China and Lilliputians: Small States in a Big Power's Evolving Foreign Policy. Asian Security, 13(2): 116-131. Available at: https://doi.org/10.1080/14799855.2017.1286159.

China's Rise to Global Economic Superpower | HuffPost. (2015). Available from https://www.huffingtonpost.com/nakem-kamrany/chinas-rise-to-global-eco b 6544924.html. [Accessed December 5, 2018]

China Northern and Southern Dynasties: Song, Qi, Liang, Chen. (2017). Available from https://www.travelchinaguide.com/intro/history/southern northern/. [Accessed November 30, 2018]

Cui, L., \& Song, M. (2018). Economic evaluation of the Belt and Road Initiative from an unimpeded trade perspective. International Journal of Logistics Research and Applications, 0(0): 1-22. Available at: https://doi.org/10.1080/13675567.2018.1492532.

Han Dynasty - Ancient History Encyclopedia. (2013). Available from https://www.ancient.eu/Han_Dynasty/. [Accessed November 30, 2018]

Hossin, M. A., Sarker, M. N. I., Xiaohua, Y., \& Frimpong, A. N. K. (2018). Development dimensions of e-commerce in Bangladesh. In Proceedings of the 2018 International Conference on Information Management \& Management Science - IMMS '18 (pp. 42-47). New York, USA. Available from https://doi.org/10.1145/3277139.3277152.

Vol. 1, No. 2, pp. $53-59$

2018

DOI: $10.53935 / 2641-5305 . v 1 i 2.8$

DOI: 10.53935/2641-5305.v1i2.8

Email: ziasociologydu@gmail.com

Funding: This study received no specific

financial support.

Article History:

Received: 27 September 2018

Revised: 18 October 2018

Accepted: 15 November 2018

Published: 10 December 2018

(9) 2018 by the authors; licensee Academic

Publishing Group Association for Computing Machinery. Available from https://doi.org/10.1145/3183586.3183593.

IMF. (2018). China's Economic Outlook in Six Charts. International Monetary Fund. Available from https://www.imf.org/en/News/Articles/2018/07/25/na072618-chinas-economic-outlook-in-six-charts. 
Islam Sarker, M. N., Hossin, M. A., Anusara, J., Chanthamith, B., \& Kumar, N. (2018). Practices of Low Carbon Economy in China: Challenges and Opportunities for Economic Development. Low Carbon Economy, 09(01): 18-32. Available at: https://doi.org/10.4236/lce.2018.91002.

Khan, S. I., Sarker, M. N. I., Huda, N., Nurullah, A. B. M., \& Zaman, M. R. (2018). Assessment of New Urban Poverty of Vulnerable Urban Dwellers in the Context of Sub-Urbanization in Bangladesh. The Journal of Social Sciences Research, 4(10): 184-193. Available at: https://doi.org/10.32861/journal.7.410.184.183.

Lam, W. (2016). Xi Jinping's Ideology and Statecraft. Chinese Law \& Government, 48(6): 409-417. Available at: https://doi.org/10.1080/00094609.2016.1241098.

Lee, S. (2017). An Institutional Analysis of Xi Jinping's Centralization of Power. Journal of Contemporary China, 26(105): 325-336. Available at: https://doi.org/10.1080/10670564.2016.1245505.

Ploberger, C. (2017). One Belt, One Road - China's new grand strategy. Journal of Chinese Economic and Business Studies, 15(3): 289-305. Available at: https://doi.org/10.1080/14765284.2017.1346922.

Rahman, M. Z., Sarker, M. N. I., Huda, N., Islam Khan, S., A. B. M., N., \& Zaman, M. R. (2018). Assessment of SocioEconomic and Sexual Vulnerability of Tea Workers in Bangladesh. The Journal of Social Sciences Research, 4(11): 229-240. Available at: https://doi.org/10.32861/jssr.411.229.240.

Sarker, M. N. I. (2016). Poverty of Island Char Dwellers in Bangladesh. Hamburg, Diplomica Publishing GmbH,Germany. Available from http://www.anchor-publishing.com/e-book/318628/poverty-of-island-chardwellers-in-bangladesh

Sarker, M. N. I., Ali, M. A., \& Islam, M. S. (2015). Causes and possible solutions of poverty perceived by char dwellers in Bangladesh. International Journal of Natural and Social Sciences, 2(21): 37-41.

Sarker, M. N. I., Bingxin, Y., Sultana, A., \& Prodhan, A. S. (2017). Problems and challenges of public administration in Bangladesh: pathway to sustainable development. International Journal of Public Administration and Policy Research, 3(1): 16-25.

Sarker, M. N. I., Hossin, M. A., Frimpong, A. N. K., \& Xiaohua, Y. (2018). Promoting information resource management for e-government through big data approach. In Proceedings of the 2018 International Conference on Information Management \& Management Science - IMMS '18 (pp. 99-104). New York, USA. Available from https://doi.org/10.1145/3277139.3277155.

Sarker, M. N. I., Hossin, M. A., Hua, Y., Sarkar, M. K., \& Kumar, N. (2018). Oil, Gas and Energy Business under One Belt One Road Strategic Context. Open Journal of Social Sciences, 06(04): 119-134. Available at: https://doi.org/10.4236/jss.2018.64011.

Sarker, M. N. I., Hossin, M. A., Hua, Y. X., Anusara, J., Warunyu, S., Chanthamith, B., ... Shah, S. (2018). Low Carbon City Development in China in the Context of New Type of Urbanization. Low Carbon Economy, 09(01): 45-61. Available at: https://doi.org/10.4236/lce.2018.91004.

Sarker, M. N. I., Hossin, M. A., Yin, X., \& Sarkar, M. K. (2018). One Belt One Road Initiative of China: Implication for Future of Global Development. Modern Economy, 09(04): 623-638. Available at: https://doi.org/10.4236/me.2018.94040.

Sarker, M. N. I., \& Jie, Z. (2017). Social Security for Vulnerable Groups in Bangladesh on Government Perspective: Contribution of Research Leader. Journal of Public Policy and Administration, 1(1): 1-9. Available at: https://doi.org/10.11648/j.jppa.20170101.11.

Sarker, M. N. I., Wu, M., \& Hossin, M. A. (2018). Smart governance through bigdata: Digital transformation of public agencies. In 2018 International Conference on Artificial Intelligence and Big Data (ICAIBD) (pp. 62-70). IEEE. Available from: https://doi.org/10.1109/ICAIBD.2018.8396168.

Sarker, M. N. I., Wu, M., Liu, R., \& Ma, C. (2019). Challenges and Opportunities for Information Resource Management for E-Governance in Bangladesh. In J. Xu et al. (Ed.), Proceedings ofthe Twelfth International Conference on Management Science and Engineering Management: Lecture Notes on Multidisciplinary Industrial Engineering (pp. 675-688). Available from: https://doi.org/10.1007/978-3-319-93351-1_53.

Sarker, N. I., Chanthamith, B., Anusara, J., Huda, N., Amin, M. Al, Jiachen, L., \& Nasrin, M. (2018). Determination of Interdisciplinary Relationship among Political Science,Social sciences and Public Administration: Perspective of Theory and Practice. Discovery, 54(273): 353-359.

Research in Social Sciences Vol. 1, No. 2, pp. 53-59 2018

DOI: $10.53935 / 2641-5305 . v 1 i 2.8$

"Corresponding Author: Md Ziaur Rahman

Emait:

Email: ziasociologydu@gmail.com

Funding: This study received no specific

financial support.

Article History:

Received: 27 September 2018

Revised: 18 October 2018

Accepted: 15 November 2018

Published: 10 December 2018

(C) 2018 by the authors; licensee Academic Publishing Group the 'One Belt One Road' imaginary. Territory, Politics, Governance, 0(0): 1-25. Available at: https://doi.org/10.1080/21622671.2018.1523746.

World Bank. (2018). The World Bank In China. Available from https://www.worldbank.org/en/country/china/overview.

Worldometers. (2018). China Population 2018. Available from http://www.worldometers.info/world-population/chinapopulation/.

Yu, H. (2017). Motivation behind China's 'One Belt, One Road' Initiatives and Establishment of the Asian Infrastructure Investment Bank. Journal of Contemporary China, 26(105): 353-368. Available at: https://doi.org/10.1080/10670564.2016.1245894. 